\title{
Development and validation of a method for the simultaneous determination of 20 organophosphorus pesticide residues in corn by accelerated solvent extraction and gas chromatography with nitrogen phosphorus detection
}

\author{
Vesna Kostik*, Biljana Gjorgeska, Bistra Angelovska \\ Medical Faculty, Department of Pharmacy, University “Goce Delchev”, Shtip, Republic of Macedonia \\ Email address: \\ vesna2mk@yahoo.com (V. Kostik), biljana.gorgeska@ugd.edu.mk (B. Gjorgeska), bistra.angelovska@ugd.edu.mk (B. Angelovska)
}

\section{To cite this article:}

Vesna Kostik, Biljana Gjorgeska, Bistra Angelovska. Development and Validation of a Method for the Simultaneous Determination of 20 Organophosphorus Pesticide Residues in Corn by Accelerated Solvent Extraction and Gas Chromatography with Nitrogen Phosphorus Detection. American Journal of Applied Chemistry. Vol. 2, No. 4, 2014, pp. 46-54. doi: 10.11648/j.ajac.20140204.11

\begin{abstract}
The method for simultaneous determination of 20 organophosphorus pesticide residues in corn samples has been developed and validated. For the extraction of organophosporus pesticide residues from the samples, the accelerated solvent technique with the mixture of dichloromethane: acetone $(1: 1, V / V)$ was used. Clean up was done using liquid - liquid extraction with $n$ - hexane, followed by solid phase extraction on primary secondary amine adsorbent, and elution with the mixture of acetone: toluene (65:35). The determination of the pesticides was carried out by gas chromatography with nitrogen phosphorus detection. Separation and quantitative determination of the analytes were performed on a fused silica capillary ZB-35 column ( $30 \mathrm{~m} \times 0.25 \mathrm{~mm}$ i.d. $\times 0.25 \mu \mathrm{m}$, Phenomenex). The recovery was investigated in blank corn samples fortified with mevinphos, diazinon, dimethoate, bromofos-methyl, chlorfenvinphos, fenamiphos, ethion and phosalone at $5 \mathrm{ng} / \mathrm{g}, 10$ $\mathrm{ng} / \mathrm{g}, 15 \mathrm{ng} / \mathrm{g}, 20 \mathrm{ng} / \mathrm{g}$ and $25 \mathrm{ng} / \mathrm{g}$, respectively and with methacrifos, phorate, etrimfos, parathion-methyl, pirimiphos methyl, fenitrothion, chlorpyrifos, malathion, parathion, bromofos-ethyl, phosmet and azinphos-methyl at $10 \mathrm{ng} / \mathrm{g}, 20 \mathrm{ng} / \mathrm{g}$, $30 \mathrm{ng} / \mathrm{g}, 40 \mathrm{ng} / \mathrm{g}$ and $50 \mathrm{ng} / \mathrm{g}$, respectively. The recovery ranged from $76.0 \%$ to $112.0 \%$. Repeatability expressed as relative standard deviation (RSD) was less than $8.2 \%$. Linearity expressed as correlation coefficient $\left(\mathrm{R}^{2}\right)$ ranged from 0.9935 to 0.9996. Measurement uncertainty $\left(\mathrm{U}_{\mathrm{x}}\right)$ was lower than $14.2 \%$ for all tested pesticides. The limits of quantification (LOQ) were bellow $5 \mathrm{ng} / \mathrm{g}$ for all tested pesticides. The satisfactory Z-score results of international proficiency tests confirm good analytical performances of the developed method.
\end{abstract}

Keywords: Organophosporus Pesticide Residues, Gas Chromatography, Accelerated Solvent Extraction, Solid Phase Extraction

\section{Introduction}

Most crops are treated with pesticides on several occasions during the growing season. Pesticides enable farmers to produce some crops in areas that otherwise would not be suitable, increase their yields, preserve product quality, and extend shelf life [1]. Without pesticides, commercial crop's production would not be economically viable in many regions of the world. Insecticides and fungicides are likely to remain the major class of pesticides used for crop's protection [2, 3]. Insecticides are used to control pests. A particular insecticide targets specific insects [2]. Fungicides are applied to control a considerable number of diseases caused by Venturia inaequalis, Uncinula necator, Sclerotinia blight, Botrytis cinerea etc [3]. At the same time, pesticides can pose risks if they are not applied according to Good Agricultural Practice (GAP). Pesticide levels tend to decline over time as the residues in crops degrade/metabolize during the growing period and following harvest if they are washed and processed before 
reaching the markets. Many authors have also shown that if pesticides are applied in accordance with GAP then the Maximum Residue Levels (MRLs) will not be exceeded. [4, 5] So, levels are usually well below legal limits by the time food reaches the retail outlets.

A large number of pesticides are used on corn, which in the Republic of Macedonia is grown throughout the country both for human consumption and animal feed [6]. Conventionally grown corn requires many applications of insect-killers, weed-killers, plant growth regulators and other types of pesticides [7]. Corn is treated with organophosphorus pesticides (OPPs) in pre harvest interval, while corn grains are treated in post harvest period for prevention the infestation with insects of stored commodities. The use of OPPs as post harvest pesticides is mainly due to the lower rate of degradation under the storage conditions that exist in storehouses. The post-harvest pesticides have been attracting much attention because their residues in stored cereal grains may be hazardous to human health [8]. The presence of OPPs residues in corn is still reported $[9,10]$. The monitoring of pesticide residues in corn and corn products is of a significant importance in terms of consumer safety.

To protect the health of consumers and to eliminate unsafe food, as well as to comply with the requirements of international food trade, MRLs of pesticide in food were laid down in Regulation (EC) 396/2005 [11]. For the majority of the studied pesticides, MRLs in corn have been established at the analytical limit of determination (between 10 and 50 $\mu \mathrm{g} / \mathrm{kg})$.

Due to the complex nature of cereals and the presence of lipids, fiber-carbohydrates (hemicellulose, cellulose and lignin), non fiber carbohydrates (starch, sucrose and reducing sugars) and proteins, the selection of the appropriate technique of extraction, concentration and purification of the pesticides, and its optimization is the most laborious, but very important aspect of the analysis [12]. A lot of different extraction and cleanup methods including multiple solvent extractions, supercritical fluid extraction (SFE), accelerated solvent extraction (ASE), gel permeation chromatography (GPC), solid phase extraction (SPE) were used in the determination of pesticides in cereals but there is no universal technique, which would be entirely better than the others in terms of all analytical scopes [13-20]. Many of the traditional procedures used to perform the extractions for these analyses are time consuming and solvent intensive $[13,17]$.

Organophosphorus pesticides are usually determined by gas chromatography (GC) with flame photometric detection (FPD) $[13,18]$, nitrogen-phosphorus detection (NPD) [14, $15,21]$, mass spectrometry detection (MS) [16, 17, 21-25], and liquid chromatography coupled with tandem mass spectrometry (LC-MS/MS) [23, 24].

The main objective of this work was to develop and validate rapid, simple and reliable analytical method for the simultaneous determination of residues of twenty OPPs: azinphos-methyl; bromofos-methyl; bromofos-ethyl; chlorfenvinphos; chlorpyrifos; diazinon; dimethoate; ethion; fenamiphos; fenitrothion; malathion; parathion; parathion-methyl; pirimiphos-methyl; phorate; phosalone; phosmet in corn including etrimfos, mevinphos and methacrifos, which have not appeared in recent reports. Extraction of the samples was performed with a low volume of organic solvent using ASE technique. $N-$ hexane was used for purification of the extracts, followed by SPE on the primary secondary amine adsorbent (PSA). The OPPs in corn samples were determined by GC - NPD.

\section{Experimental}

\subsection{Instrumentation}

The sample extraction was performed in a DIONEX Accelerated Solvent extractor, ASE-100 (USA). Stainless steel extraction cells $(10 \mathrm{~mL})$ were used for the extraction. Helium (purity $99.999 \%$ ) was used as a purge gas.

The chromatographic analysis was performed on a Shimadzu 2010 Gas Chromatography system (GC) system equipped with nitrogen-phosphorus detector (NPD), and auto injector (AOC- 20i), and the ChromSolution software. Chromatographic separation was achieved on a fused silica ZB-35 capillary column ( $30 \mathrm{~m}$ x $0.25 \mathrm{~mm}$ i.d. x $0.25 \mu \mathrm{m}$ film thickness), supplied by Phenomenex (Torrance, USA). Operating conditions were as follows: injector port temperature, $250{ }^{0} \mathrm{C}$; injection volume, $2 \mu \mathrm{L}$ in splitless mode (constant pressure $110.8 \mathrm{kPa}$; total flow $10.2 \mathrm{~mL} / \mathrm{min}$ ); detector temperature $280{ }^{\circ} \mathrm{C}$ (make up gas - helium flow $27.5 \mathrm{~mL} / \mathrm{min}$; hydrogen flow $1.5 \mathrm{~mL} / \mathrm{min}$; air flow 145 $\mathrm{mL} / \mathrm{min}$; current $3 \mathrm{pA}$ ); helium as carrier gas at a flow rate of $1.2 \mathrm{~mL} / \mathrm{min}$; oven temperature programme, $90{ }^{0} \mathrm{C}(1 \mathrm{~min})$, increased with the rate of $25{ }^{\circ} \mathrm{C} / \mathrm{min}$ to $200{ }^{\circ} \mathrm{C}$, held for 15 min, then increased to $220{ }^{\circ} \mathrm{C}$ with the rate of $10{ }^{\circ} \mathrm{C}$ min, and held for $25 \mathrm{~min}$. The total run time of the chromatographic analysis was $47.40 \mathrm{~min}$. The column equilibration time was 3 min.

\subsection{Reagents and Chemicals}

All chemicals and solvents were a special grade for pesticide residue analysis. Acetone, dichloromethane (DCM), $n$-hexane, ethyl acetate, acetonitrile (ACN) and toluene were obtained from Merck (Darmstadt, Germany). Anhydrous sodium sulphate, (prepared 3 hours at $650{ }^{\circ} \mathrm{C}$ ), sodium chloride and PSA /SPE cartridges (PSA, SPE $500 \mathrm{mg} / 6 \mathrm{~mL}$ tubes) were purchased from Sigma-Aldrich/Fluka/Riedel-de-Haen (Zwijndrecht, The Netherlands). Water was deionized then distilled from glass apparatus.

The analytical standards of azinphos-methyl $(97.3 \% \pm 2)$, bromofos-methyl $(98.5 \% \pm 2)$, bromofos-ethyl $(99.7 \% \pm 5)$, chlorfenvinphos $(99.0 \% \pm 5)$, chlorpyrifos $(98.0 \% \pm 5)$, diazinon $(99.2 \% \pm 5)$, dimethoate $(98.5 \% \pm 2)$, ethion $(98.0 \% \pm 2)$, etrimfos $(95.0 \% \pm 5)$, fenamiphos $(95.5 \% \pm 2)$, fenitrothion $(95.2 \% \pm 5)$, malathion $(97.2 \% \pm 2)$, mevinphos $(98.0 \% \pm 5)$, methacrifos $(98.5 \% \pm 5)$, parathion $(99.7 \pm 2)$, parathion-methyl $(99.8 \pm 5)$, pirimiphos-methyl 
$(99.3 \% \pm 5)$; phorate $(95.8 \% \pm 5)$; phosalone $(99.0 \pm 5)$ and phosmet $(97.0 \% \pm 5)$ were obtained from Sigma-Aldrich/Fluka/Riedel-de-Haen (Zwijndrecht, The Netherlands). Blank corn samples were purchased from FAPAS (CSL, York, UK).

\subsection{Preparation of the Standard Solutions}

Stock solutions of individual pesticide standards were prepared in acetone at $500 \mu \mathrm{g} / \mathrm{mL}$ and stored in a refrigerator at $4{ }^{0} \mathrm{C}$. Standard working solution mixture (i) was prepared by transferring $5 \mathrm{~mL}$ of each individual stock standard solution in a $50 \mathrm{~mL}$ volumetric flask and diluting with methanol to a concentration of $50 \mu \mathrm{g} / \mathrm{mL}$. Standard working solution mixture (ii) was prepared by transferring $2.5 \mathrm{~mL}$ of working solution mixture (i) in a $25 \mathrm{~mL}$ volumetric flask and diluting with methanol to a concentration of $5 \mu \mathrm{g} / \mathrm{mL}$. Standard working solution mixture (iii) was prepared by transferring $5 \mathrm{~mL}$ of the standard working solution mixture (ii) in a $50 \mathrm{~mL}$ volumetric flask and diluting with methanol to a $0.5 \mu \mathrm{g} / \mathrm{mL}$. Standard working solution mixtures (ii, iii) were used for the fortification of blank samples. Standard working solution mixtures (i, ii) were used for the preparation of chromatographic standard solutions with different pesticide concentrations: $25 \mathrm{ng} / \mathrm{mL}$ - $125 \mathrm{ng} / \mathrm{mL}$, i.e. $25 \mathrm{ng} / \mathrm{mL}$; 50 $\mathrm{ng} / \mathrm{mL} ; 75 \mathrm{ng} / \mathrm{mL} ; 100 \mathrm{ng} / \mathrm{mL}$ and $125 \mathrm{ng} / \mathrm{mL}$ for mevinphos, diazinon, dimethoate, bromofos-methyl, chlorfenvinphos, fenamiphos, ethion and phosalone; 50 - $250 \mathrm{ng} / \mathrm{mL}$, i.e. 50 $\mathrm{ng} / \mathrm{mL} ; 100 \mathrm{ng} / \mathrm{mL} ; 150 \mathrm{ng} / \mathrm{mL} ; 200 \mathrm{ng} / \mathrm{mL}$ and $250 \mathrm{ng} / \mathrm{mL}$ for methacrifos, phorate, etrimfos, parathion-methyl, pirimiphos - methyl, fenitrothion, chlorpyrifos, malathion, parathion, bromofos-ethyl, phosmet and azinphos-methyl. Chromatographic standard solutions were prepared in a 10 $\mathrm{mL}$ volumetric flask class A, using ethyl acetate as a solvent.

\subsection{Sample Preparation}

An aliquot of $5 \mathrm{~g}$ of grinded sample was mixed with $2.5 \mathrm{~g}$ of anhydrous sodium sulphate. The extraction cell was filled with the homogenized mixture, and placed in the ASE, which worked out under the conditions shown in Table 1.

Table 1. ASE operating conditions

\begin{tabular}{ll}
\hline Solvent & DCM/acetone $(\mathbf{1 : 1 ,} \boldsymbol{V} / \boldsymbol{V})$ \\
\hline Temperature & $100{ }^{\circ} \mathrm{C}$ \\
Pressure & $1500 \mathrm{psi}$ \\
Static time & $5 \mathrm{~min}$ \\
Flush volume & $60 \%$ \\
Purge time & $140 \mathrm{sec}$ \\
Static Cycle & 1 \\
\hline
\end{tabular}

The obtained extract $(15 \mathrm{~mL})$ was transferred into the separating funnel. $200 \mathrm{~mL}(10 \%, W / V)$ sodium chloride in deionized water and $50 \mathrm{~mL}$ of $n$-hexane were added and vigorously shaken for $5 \mathrm{~min}$ and then allowed to stand for 15 min. The water portion was discarded. The hexane layer was collected through the anhydrous sodium sulphate and removed by a rotary evaporator at $40{ }^{\circ} \mathrm{C}$. The residue was dissolved in $\mathrm{ACN}$ and adjusted to the volume of $1 \mathrm{~mL}$ with the same solvent.

Sample cleanup: $6 \mathrm{~mL}$ column (PSA) was conditioned with $5 \mathrm{~mL}$ mixture of acetone: toluene (65:35). $1 \mathrm{~mL}$ of the sample was transferred to a column. Pesticides were eluted from the column with $20 \mathrm{~mL}$ mixture of acetone: toluene (65:35). The eluted solution was concentrated to $0.5 \mathrm{~mL}$ by a gentle stream of nitrogen at $40{ }^{\circ} \mathrm{C}$. The volume was adjusted to $1 \mathrm{~mL}$ by adding of ethyl acetate. The sample solution was used for GC-NPD determination.

The proposed method was validated in respect to the recovery, linearity, precision expressed as within day repeatability and between day reproducibility of retention time and peak area, stability, limit of detection (LOQ), limit of quantification (LOQ) and measurement uncertainty $\left(\mathrm{U}_{\mathrm{x}}\right)$.

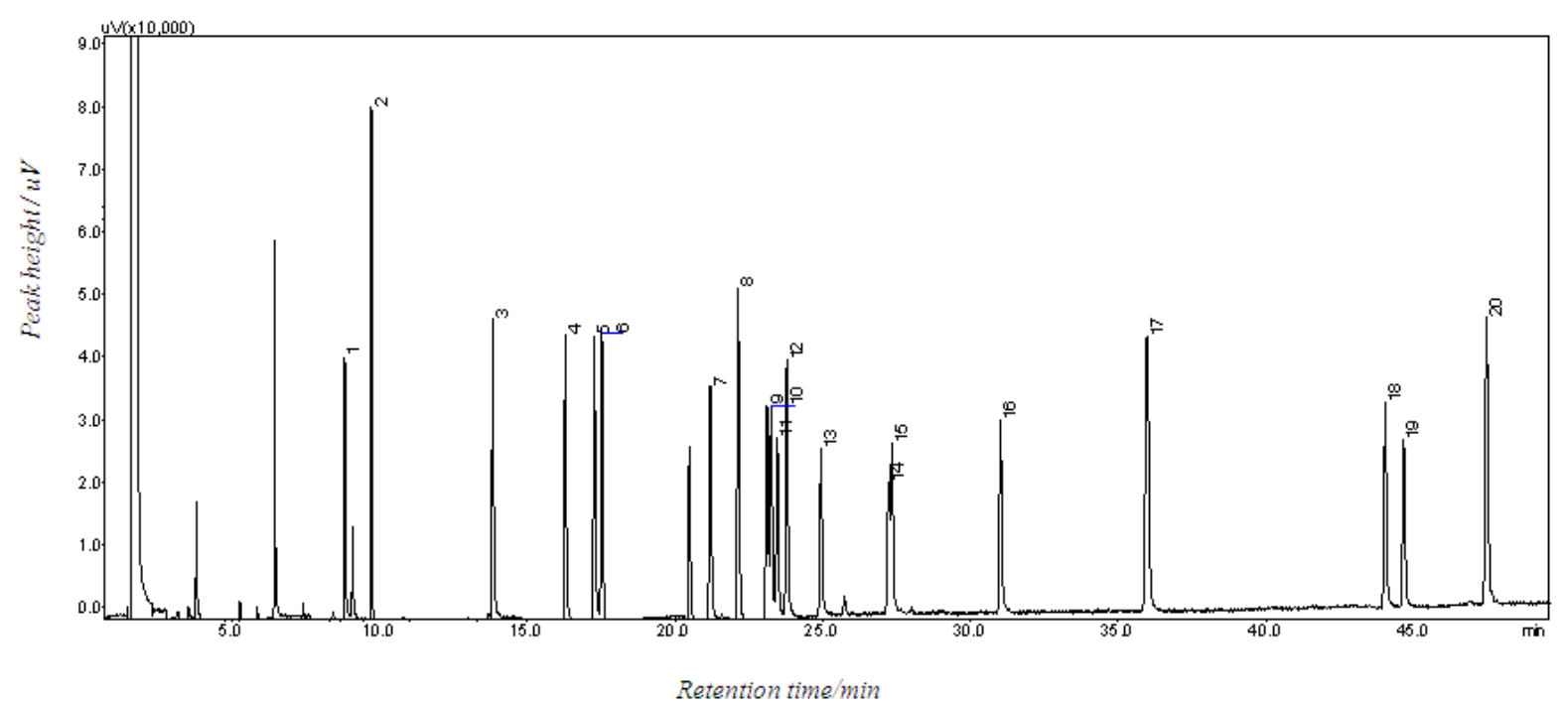

Figure 1. GC-NPD chromatogram of standard solution with OPPs in ethyl acetate at $0.1 \mathrm{mg} / \mathrm{L}:$ (1) mevinphos, (2) methacrifos, (3) phorate, (4) diazinon, (5) dimethoate, (6) etrimfos, (7) parathion-methyl, (8) pirimiphos-methyl, (9) fenitrothion, (10) chlorpyrifos, (11) malathion, (12) parathion, (13) bromophos - methyl, (14) chlorfenvinphos, (15) bromofos - ethyl, (16) fenamiphos, (17) ethion, (18) phosmet, (19) phosalone, (20) azinphos - methyl. 


\section{Results and Discussion}

\subsection{Method Optimization}

In order to obtain the best separation and get symmetrical peak shapes for all tested pesticides, a series of preliminary investigations with capillary GC columns with a different polarity of the stationary phase were tested. The optimum separation of components of interest was achieved when capillary column with an intermediate polarity (35\% phenyl $65 \%$ dimethylpolysiloxane) and optimized temperature programme is used (Fig. 1).

In our research ASE technique was used for samples extraction. To obtain higher recovery for pesticides and to reduce the amount of co-extractable lipids which require extensive purification procedures as a gel permeation chromatography (GPC), we used a zeotropic mixture of DCM: acetone $(1: 1, V / V)$ as an extraction solvent. In the investigations of Ezzell et al., high recoveries for OPPs in fortified apple puree $(0.05 \mathrm{mg} / \mathrm{kg})$, ranging from $82 \%$ for fenthion to $128 \%$ for dimethoate were obtained with ASE and azeoptropic mixture of ethyl acetate: cyclohexane $(1: 1$, $V / V)$, followed by purification with GPC [20].

Due to the use of elevated temperature and pressure in the extraction cell the extraction time in our experiment was approximately $15 \mathrm{~min}$. The presence of cellulose filter disk in the outlet end of the extraction cell provided the clear extract, and there was no need for further filtration.

ASE is generally considered to be an exhaustive extraction technique, and often the extracts obtained from complex samples contain compounds that can interfere in the determination of the desired analytes $[19,20]$. Therefore, the purification of the obtained extract was performed. In order to remove the lipids from the extract, we introduced liquid-liquid extraction with $n$-hexane in the presence of $10 \%(W / V) \mathrm{NaCl}$ in deionized water. In the study of Hirara et al. after multiple extractions of the sample with ACN and ethyl acetate, the lipid fraction was removed by addition of the mixture of ACN saturated with $n$-hexane and $n$-hexane saturated with ACN [17]. In a study conducted by Tang et al. DCM was used for purification after acetone-water extraction of cereals and kidney beans prior to GC-NPD determination of nine OPPs [13].

In our study an additional purification of the extract was performed in order to remove the residual lipid fraction. For that purposes we used SPE tubes containing PSA adsorbent. Florisil (magnesium silicate) is material mostly used in sample purification prior to GC analysis of organochlorine compounds, nitrosamines, aliphatic and aromatic compounds, etc. [19]. But, when used for purification of matrices that contain organophosphorus pesticides which have phosphorus - oxygen bond, a decomposition of the pesticide may occur, which yields a poor recovery [16]. Liu and Ma obtained a low recovery for dimethoate in corn $(2.65 \%$ for $0.25 \mathrm{mg} / \mathrm{kg}$ and $9.0 \%$ for $1.0 \mathrm{mg} / \mathrm{kg}$, respectively) using florisil for the purification of the extract [16]. Hirara et al. used strong anion exchange
(SAX) resin in combination with PSA for purification of the extracts obtained for fruit, vegetable and cereal samples, prior to GC-MS analysis of 186 pesticides [17]. They obtained low recovery for polar pesticides (omethoate), which was probably due to the insufficient elution with acetone: $n$-hexane $(3+7)$ from a SAX-PSA cartridge. Mariani et al. found out the use of deactivated acidic alumina with the elution solvent consisted of $n$-hexane: DCM: ethyl acetate $(6+3+1, V / V)$ preferable versus a low temperature lipid precipitation in removal of high molecular weight compounds prior to GC-NPD analysis of the OPPs in cereal extracts [14].

We use PSA also for the elimination of non-polar molecular components in the corn extracts (carotenoid pigments). This is based on its combined hydrophilic and lipophilic characteristics.

At the evaluation step of cleanup method, three different volumes $(5 \mathrm{~mL}, 10 \mathrm{~mL}, 20 \mathrm{~mL})$ of the solvent mixture acetone: toluene $(65: 35)$ was used for the elution of the OPPs from the PSA column. Optimization of the elution volume was done with standard mixture of OPPs in ACN at a concentration of $50 \mathrm{ng}$. The extracts were evaporated to 0.5 $\mathrm{mL}$ after the SPE and reconstituted in $n$-hexane: acetone $(1: 1)$. Analysis was performed by GC-NPD. The results of our study for recovery evaluation of pesticides in correlation with the volume of elution solvent acetone: toluene $(65: 35)$ presented in Table 2 show the highest recovery of all the pesticides with $20 \mathrm{~mL}$ of the elution mixture. The obtained recoveries are between $88.3 \%$ for chlorfenvinphos and $120.2 \%$ for etrimfos. In their study Schenck et al. found also high recoveries for parathion-methyl (94\%) and ethion (92\%), when they used $20 \mathrm{~mL}$ of elution solvent acetone: toluene $(65: 35)$ on PSA/carbon adsorbent in the purification of onion extracts[26].

Table 2. Optimization of elution solvent volume (Recovery evaluation for tested pesticides)

\begin{tabular}{llll}
\hline \multirow{2}{*}{ Pesticide } & \multicolumn{2}{l}{ Recovery (\%); $\mathbf{~} \mathbf{3}$} \\
\cline { 2 - 4 } & $\mathbf{5} \mathbf{~ \mathbf { L }}$ & $\mathbf{1 0} \mathbf{~ m L}$ & $\mathbf{2 0} \mathbf{~ m L}$ \\
\hline Mevinphos & 45.5 & 89.3 & 95.8 \\
Methacrifos & 58.6 & 98.8 & 117.3 \\
Phorate & 34.4 & 75.6 & 88.9 \\
Diazinon & 44.5 & 77.6 & 90.3 \\
Dimethoate & 37.9 & 69.8 & 91.2 \\
Etrimfos & 55.6 & 79.8 & 120.2 \\
Parathion-methyl & 49.8 & 80.1 & 115.3 \\
Pirimiphos-methyl & 55.6 & 81.2 & 98.8 \\
Fenitrothion & 44.3 & 78.8 & 110.5 \\
Chlorpyriphos & 39.7 & 80.2 & 94.5 \\
Malathion & 44.5 & 87.6 & 110.4 \\
Parathion & 33.4 & 76.6 & 104.5 \\
Bromofos-methyl & 45.6 & 78.9 & 95.3 \\
Chlorfenvinphos & 37.5 & 69.8 & 88.3 \\
Bromofos-ethyl & 49.8 & 78.3 & 98.6 \\
Fenamiphos & 41.2 & 70.3 & 94.4 \\
Ethion & 40.4 & 79.8 & 97.3 \\
Phosmet & 35.6 & 67.5 & 89.5 \\
Phosalone & 39.8 & 70.7 & 93.2 \\
Azinphos-methyl & 44.0 & 76.3 & 98.2 \\
\hline
\end{tabular}




\subsection{Method Validation}

\subsubsection{Recovery, Precision and Linearity}

The recovery, precision and linearity of all the organophosphus pesticides was determined using fortified blank corn samples which were previously tested on the presence of OPPs. In each case, 5 replicates each at 5 levels were fortified into the samples. The samples $(5 \mathrm{~g})$ were fortified before the extraction with $50 \mu \mathrm{L}$ of $0.5 \mathrm{ng} / \mu \mathrm{L}$ mixture to yield $5 \mathrm{ng} / \mathrm{g}$ (mevinphos, diazinon, dimethoate, bromofos-methyl, chlorfenvinphos, fenamiphos, ethion and phosalone); with $10 \mu \mathrm{L}, 15 \mu \mathrm{L}, 20 \mu \mathrm{L}$ and $25 \mu \mathrm{l}$ of the 5.0 $\mathrm{ng} / \mu \mathrm{L}$ spiking mixture to yield $10 \mathrm{ng} / \mathrm{g}, 15 \mathrm{ng} / \mathrm{g}, 20 \mathrm{ng} / \mathrm{g}$ and $25 \mathrm{ng} / \mathrm{g}$, respectively (mevinphos, diazinon, dimethoate, bromofos-methyl, chlorfenvinphos, fenamiphos, ethion and phosalone); and with $10 \mu \mathrm{L}, 20 \mu \mathrm{L}, 30 \mu \mathrm{L}, 40 \mu \mathrm{L}$ and $50 \mu \mathrm{L}$ of the $5.0 \mathrm{ng} / \mu \mathrm{L}$ spiking mixture to yield $10 \mathrm{ng} / \mathrm{g}, 20 \mathrm{ng} / \mathrm{g}$, $30 \mathrm{ng} / \mathrm{g}, 40 \mathrm{ng} / \mathrm{g}$ and $50 \mathrm{ng} / \mathrm{g}$, respectively (methacrifos, phorate, etrimfos, parathion-methyl, pirimiphos - methyl, fenitrothion, chlorpyrifos, malathion, parathion, bromofos-ethyl, phosmet and azinphos-methyl). Gas tight glass syringes $(10 \mu \mathrm{L}, 50 \mu \mathrm{L}$ and $100 \mu \mathrm{L})$ were use for the addition of spiking mixtures.

According to a guidance document on pesticide residue analytical methods, the precision of the proposed method should be presented as a relative standard deviation (RSD) of the recovery at each fortification level. The linearity of the method was expressed as correlation coefficient $\left(R^{2}\right)$, obtained from regression analysis of the fortified samples [27].

The recovery, precision and linearity of the tested method are presented in Table 3 .

The obtained values for recovery and RSD are between $76.0 \%$ and $112.0 \%$ and $1.1 \%-8.2 \%$, respectively. According to the EU criteria the mean recovery at each fortification level should be in the range of $70 \%-120 \%$ with $\mathrm{RSD} \leq 20 \%$ [27].

Table 3. Statistical data for mean recovery, precision data and linearity of the method

\begin{tabular}{|c|c|c|c|c|c|}
\hline Pesticide & Fortification level (mg/kg) & Pesticide found - mean value $(\mathrm{mg} / \mathrm{kg} \pm \mathrm{SD})$ & Recovery $(\%), n=5$ & RSD (\%) & Regression equation \\
\hline \multirow{5}{*}{ Mevinphos } & 0.005 & $0.0045 \pm 0.0003$ & 90.0 & 6.6 & \multirow{5}{*}{$\begin{array}{l}y=1.004 \mathrm{x}-0.0006 \\
R^{2}=0.9991\end{array}$} \\
\hline & 0.010 & $0.0092 \pm 0.0005$ & 92.0 & 5.4 & \\
\hline & 0.015 & $0.0143 \pm 0.0007$ & 95.3 & 4.9 & \\
\hline & 0.020 & $0.0198 \pm 0.0008$ & 99.0 & 4.0 & \\
\hline & 0.025 & $0.0243 \pm 0.0009$ & 97.2 & 3.7 & \\
\hline \multirow{5}{*}{ Methacrifos } & 0.010 & $0.0110 \pm 0.0002$ & 110.0 & 1.8 & \multirow{5}{*}{$\begin{array}{l}y=0.945 x+0.0004 \\
R^{2}=0.9961\end{array}$} \\
\hline & 0.020 & $0.0185 \pm 0.0005$ & 92.5 & 2.7 & \\
\hline & 0.030 & $0.0275 \pm 0.0006$ & 91.7 & 2.2 & \\
\hline & 0.040 & $0.0380 \pm 0.0007$ & 95.0 & 1.8 & \\
\hline & 0.050 & $0.0485 \pm 0.0008$ & 97.0 & 1.6 & \\
\hline \multirow{5}{*}{ Phorate } & 0.010 & $0.0082 \pm 0.0002$ & 82.0 & 2.4 & \multirow{5}{*}{$\begin{array}{l}y=0.911 \mathrm{x}-0.0004 \\
R^{2}=0.9969\end{array}$} \\
\hline & 0.020 & $0.0175 \pm 0.0006$ & 87.5 & 3.4 & \\
\hline & 0.030 & $0.0281 \pm 0.0005$ & 93.4 & 1.8 & \\
\hline & 0.040 & $0.0364 \pm 0.0004$ & 91.0 & 1.1 & \\
\hline & 0.050 & $0.0443 \pm 0.0006$ & 88.6 & 1.3 & \\
\hline \multirow{5}{*}{ Diazinon } & 0.005 & $0.0038 \pm 0.0003$ & 76.0 & 7.9 & \multirow{5}{*}{$\begin{array}{l}y=0.968 x-0.0011 \\
R^{2}=0.9954\end{array}$} \\
\hline & 0.010 & $0.0083 \pm 0.0003$ & 83.0 & 3.6 & \\
\hline & 0.015 & $0.0140 \pm 0.0005$ & 80.7 & 3.6 & \\
\hline & 0.020 & $0.0175 \pm 0.0006$ & 87.5 & 3.4 & \\
\hline & 0.025 & $0.0234 \pm 0.0007$ & 93.6 & 3.0 & \\
\hline \multirow{5}{*}{ Dimethoate } & 0.005 & $0.0041 \pm 0.0003$ & 82.0 & 7.3 & \multirow{5}{*}{$\begin{array}{l}y=0.992 \mathrm{x}-0.0012 \\
R^{2}=0.9964\end{array}$} \\
\hline & 0.010 & $0.0087 \pm 0.0005$ & 87.0 & 5.7 & \\
\hline & 0.015 & $0.0129 \pm 0.0007$ & 86.0 & 5.4 & \\
\hline & 0.020 & $0.0185 \pm 0.0006$ & 92.5 & 3.2 & \\
\hline & 0.025 & $0.0240 \pm 0.0008$ & 96.0 & 3.3 & \\
\hline \multirow{5}{*}{ Etrimfos } & 0.010 & $0.0112 \pm 0.0005$ & 112.0 & 4.5 & \multirow{5}{*}{$\begin{array}{l}y=0.911 x+0.0016 \\
R^{2}=0.9994\end{array}$} \\
\hline & 0.020 & $0.0195 \pm 0.0006$ & 97.5 & 3.1 & \\
\hline & 0.030 & $0.0287 \pm 0.0008$ & 95.7 & 2.8 & \\
\hline & 0.040 & $0.0380 \pm 0.0005$ & 95.0 & 1.3 & \\
\hline & 0.050 & $0.0475 \pm 0.0007$ & 95.0 & 1.5 & \\
\hline \multirow{5}{*}{$\begin{array}{l}\text { Parathion- } \\
\text { methyl }\end{array}$} & 0.010 & $0.0102 \pm 0.0006$ & 102.0 & 5.9 & \multirow{5}{*}{$\begin{array}{l}y=0.983 x-0.0005 \\
R^{2}=0.9966\end{array}$} \\
\hline & 0.020 & $0.0187 \pm 0.0008$ & 93.5 & 4.3 & \\
\hline & 0.030 & $0.0277 \pm 0.0007$ & 92.3 & 2.5 & \\
\hline & 0.040 & $0.0396 \pm 0.0008$ & 99.0 & 2.0 & \\
\hline & 0.050 & $0.0489 \pm 0.0006$ & 97.8 & 1.3 & \\
\hline \multirow{3}{*}{$\begin{array}{l}\text { Pirimiphos- } \\
\text { methyl }\end{array}$} & 0.010 & $0.0095 \pm 0.005$ & 95.0 & 5.3 & \multirow{3}{*}{$\begin{array}{l}y=1.015 x-0.0018 \\
R^{2}=0.9935\end{array}$} \\
\hline & 0.020 & $0.0180 \pm 0.007$ & 90.0 & 3.9 & \\
\hline & 0.030 & $0.0276 \pm 0.006$ & 92.0 & 2.2 & \\
\hline
\end{tabular}


51 Vesna Kostik et al.: Development and Validation of a Method for the Simultaneous Determination of 20 Organophosphorus

Pesticide Residues in Corn by Accelerated Solvent Extraction and Gas Chromatography with Nitrogen Phosphorus Detection

\begin{tabular}{|c|c|c|c|c|c|}
\hline Pesticide & Fortification level (mg/kg) & Pesticide found - mean value $(\mathrm{mg} / \mathrm{kg} \pm \mathrm{SD})$ & Recovery $(\%), n=5$ & RSD (\%) & Regression equation \\
\hline \multirow{7}{*}{ Fenitrothion } & 0.040 & $0.0375 \pm 0.008$ & 93.7 & 2.1 & \multirow{7}{*}{$\begin{array}{l}y=1.001 \mathrm{x}+0.0001 \\
R^{2}=0.9987\end{array}$} \\
\hline & 0.050 & $0.0505 \pm 0.009$ & 101.0 & 1.8 & \\
\hline & 0.010 & $0.0102 \pm 0.006$ & 102.0 & 5.9 & \\
\hline & 0.020 & $0.0195 \pm 0.009$ & 97.5 & 4.6 & \\
\hline & 0.030 & $0.0310 \pm 0.008$ & 103.3 & 2.6 & \\
\hline & 0.040 & $0.0404 \pm 0.006$ & 101.0 & 1.5 & \\
\hline & 0.050 & $0.0498 \pm 0.007$ & 99.6 & 1.4 & \\
\hline \multirow{5}{*}{ Chlorpyrifos } & 0.010 & $0.0089 \pm 0.006$ & 89.0 & 6.7 & \multirow{5}{*}{$\begin{array}{l}y=0.988 x-0.001 \\
R^{2}=0.9995\end{array}$} \\
\hline & 0.020 & $0.0190 \pm 0.004$ & 95.0 & 2.1 & \\
\hline & 0.030 & $0.0280 \pm 0.007$ & 93.3 & 2.5 & \\
\hline & 0.040 & $0.0386 \pm 0.005$ & 96.5 & 1.3 & \\
\hline & 0.050 & $0.0485 \pm 0.009$ & 97.0 & 1.8 & \\
\hline \multirow{5}{*}{ Malathion } & 0.010 & $0.0104 \pm 0.005$ & 104.0 & 4.8 & \multirow{5}{*}{$\begin{array}{l}y=0.958 \mathrm{x}+0.0004 \\
R^{2}=0,9957\end{array}$} \\
\hline & 0.020 & $0.0184 \pm 0.004$ & 92.0 & 2.2 & \\
\hline & 0.030 & $0.0305 \pm 0.009$ & 101.7 & 2.9 & \\
\hline & 0.040 & $0.0380 \pm 0.007$ & 95.0 & 1.8 & \\
\hline & 0.050 & $0.0485 \pm 0.006$ & 97.0 & 1.2 & \\
\hline \multirow{5}{*}{ Parathion } & 0.010 & $0.0095 \pm 0.007$ & 95.0 & 7.4 & \multirow{5}{*}{$\begin{array}{l}y=0.986 \mathrm{x}-0.001 \\
R^{2}=0,9945\end{array}$} \\
\hline & 0.020 & $0.0190 \pm 0.008$ & 94.9 & 4.2 & \\
\hline & 0.030 & $0.0265 \pm 0.009$ & 88.3 & 3.4 & \\
\hline & 0.040 & $0.0390 \pm 0.007$ & 97.5 & 1.8 & \\
\hline & 0.050 & $0.0488 \pm 0.010$ & 97.6 & 2.0 & \\
\hline \multirow{5}{*}{$\begin{array}{l}\text { Bromofos- } \\
\text { methyl }\end{array}$} & 0.005 & $0.0044 \pm 0.005$ & 88.0 & 6.8 & \multirow{5}{*}{$\begin{array}{l}y=0.978 x-0.0009 \\
R^{2}=0,997\end{array}$} \\
\hline & 0.010 & $0.0085 \pm 0.007$ & 85.0 & 8.2 & \\
\hline & 0.015 & $0.0138 \pm 0.007$ & 92.0 & 5.1 & \\
\hline & 0.020 & $0.0182 \pm 0.006$ & 92.1 & 3.0 & \\
\hline & 0.025 & $0.0240 \pm 0.008$ & 96.0 & 3.3 & \\
\hline \multirow{5}{*}{$\begin{array}{l}\text { Chlorfenvin } \\
\text { phos }\end{array}$} & 0.005 & $0.0043 \pm 0.003$ & 86.0 & 3.5 & \multirow{5}{*}{$\begin{array}{l}y=0.934 x-0.0007 \\
R^{2}=0,9947\end{array}$} \\
\hline & 0.010 & $0.0080 \pm 0.005$ & 80.0 & 6.2 & \\
\hline & 0.015 & $0.0134 \pm 0.004$ & 89.3 & 4.5 & \\
\hline & 0.020 & $0.0187 \pm 0.005$ & 93.5 & 5.3 & \\
\hline & 0.025 & $0.0223 \pm 0.006$ & 89.2 & 6.7 & \\
\hline \multirow{5}{*}{$\begin{array}{l}\text { Bromofos- } \\
\text { ethyl }\end{array}$} & 0.010 & $0.0095 \pm 0.0004$ & 95.0 & 4.2 & \multirow{5}{*}{$\begin{array}{l}y=0.903 x+0.0007 \\
R^{2}=0,9973\end{array}$} \\
\hline & 0.020 & $0.0187 \pm 0.0007$ & 93.5 & 3.7 & \\
\hline & 0.030 & $0.0278 \pm 0.0006$ & 92.6 & 2.1 & \\
\hline & 0.040 & $0.0380 \pm 0.0005$ & 95.0 & 1.3 & \\
\hline & 0.050 & $0.0450 \pm 0.0008$ & 90.0 & 1.8 & \\
\hline \multirow{5}{*}{ Fenamiphos } & 0.005 & $0.0048 \pm 0.0003$ & 96.0 & 6.2 & \\
\hline & 0.010 & $0.0089 \pm 0.0005$ & 89.0 & 5.6 & \\
\hline & 0.015 & $0.0145 \pm 0.0005$ & 96.6 & 3.4 & $\begin{array}{l}y=0.996 x-0.0005 \\
R^{2}=0.9983\end{array}$ \\
\hline & 0.020 & $0.0195 \pm 0.0007$ & 97.5 & 3.6 & \\
\hline & 0.025 & $0.0244 \pm 0.0007$ & 97.6 & 2.9 & \\
\hline & 0.005 & $0.0047 \pm 0.0003$ & 94.0 & 6.0 & \\
\hline & 0.010 & $0.0093 \pm 0.0004$ & 93.0 & 4.0 & \\
\hline Ethion & 0.015 & $0.0140 \pm 0.0007$ & 91.3 & 4.7 & $\begin{array}{l}y=0.932 \mathrm{x}-6 \mathrm{E}-0.5 \\
R^{2}=0.9996\end{array}$ \\
\hline & 0.020 & $0.0185 \pm 0.0005$ & 92.5 & 2.5 & \\
\hline & 0.025 & $0.0234 \pm 0.0008$ & 93.6 & 3.2 & \\
\hline & 0.010 & $0.0085 \pm 0.0004$ & 85.0 & 4.7 & \\
\hline & 0.020 & $0.0182 \pm 0.0006$ & 91.0 & 6.6 & \\
\hline Phosmet & 0.030 & $0.0290 \pm 0.0006$ & 96.7 & 6.2 & $\begin{array}{l}y=1.015 \mathrm{x}-0.0017 \\
R^{2}=0.0995\end{array}$ \\
\hline & 0.040 & $0.0393 \pm 0.0008$ & 98.2 & 5.1 & \\
\hline & 0.050 & $0.0487 \pm 0.0004$ & 97.4 & 4.1 & \\
\hline & 0.005 & $0.0044 \pm 0.0003$ & 88.0 & 6.8 & \\
\hline & 0.010 & $0.0089 \pm 0.0005$ & 89.0 & 5.6 & \\
\hline Phosalone & 0.015 & $0.0144 \pm 0.0006$ & 96.0 & 4.2 & $\begin{array}{l}y=1.062 x-0.0014 \\
R^{2}=0.9943\end{array}$ \\
\hline & 0.020 & $0.0190 \pm 0.0004$ & 95.0 & 2.1 & \\
\hline & 0.025 & $0.0259 \pm 0.0007$ & 103.6 & 2.7 & \\
\hline & 0.010 & $0.0092 \pm 0.0003$ & 92.0 & 3.3 & \\
\hline & 0.020 & $0.0180 \pm 0.0005$ & 90.0 & 2.8 & \\
\hline Azinphos- & 0.030 & $0.0265 \pm 0.0004$ & 88.3 & 1.5 & $\begin{array}{l}y=0.972 \mathrm{x}+0.0013 \\
R^{2}=0.9969\end{array}$ \\
\hline & 0.040 & $0.0380 \pm 0.0006$ & 95.0 & 1.6 & \\
\hline & 0.050 & $0.0478 \pm 0.0005$ & 95.6 & 1.1 & \\
\hline
\end{tabular}




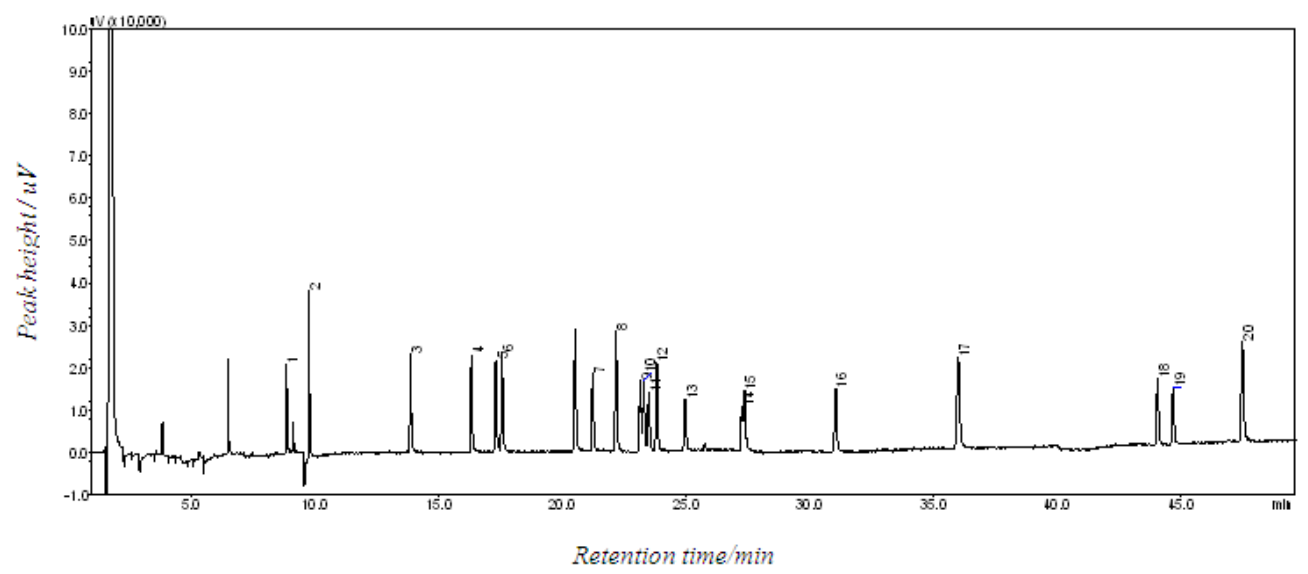

(a)

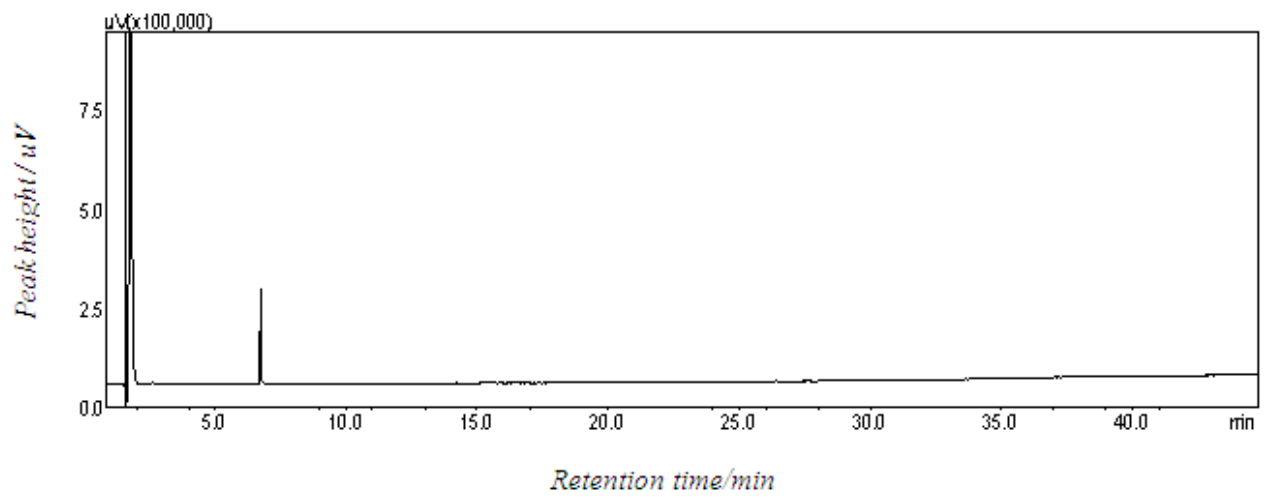

(b)

Figure 2. GC-NPD chromatograms: (a) fortified blank sample with OPPs at $10 \mathrm{ng} / \mathrm{g}(0.05 \mathrm{mg} / \mathrm{L})$ : (1) mevinphos, (2) methacrifos, (3) phorate, (4) diazinon, (5) dimethoate, (6) etrimfos, (7) parathion-methyl, (8) pirimiphos-methyl, (9) fenitrothion, (10) chlorpyrifos, (11) malathion, (12) parathion, (13) bromophos - methyl, (14) chlorfenvinphos, (15) bromofos - ethyl, (16) fenamiphos, (17) ethion, (18) phosmet, (19) phosalone, (20) azinphos - methyl :(b) blank corn extract

Table 4. Statistical data for within day repeatability and between day reproducibility

\begin{tabular}{llllll}
\hline Pesticide & $\boldsymbol{t}_{\mathbf{R}} / \mathbf{m i n}$ & $\begin{array}{l}\text { Within day } \\
\text { Repeatibility } \\
\text { (RSD, \%); n=10 }\end{array}$ & $\begin{array}{l}\text { Between day } \\
\text { Reproducibility } \\
\text { (RSD, \%); n=25 }\end{array}$ \\
\hline Mevinphos & 8.834 & 0.102 & 3.17 & 0.155 & 4.11 \\
Methacrifos & 9.741 & 0.113 & 0.91 & 0.172 & 1.23 \\
Phorate & 13.847 & 0.130 & 1.40 & 0.169 & 1.78 \\
Diazinon & 16.299 & 0.092 & 2.73 & 0.118 & 3.34 \\
Dimethoate & 17.281 & 0.121 & 3.61 & 0.144 & 4.35 \\
Etrimfos & 17.540 & 0.103 & 3.23 & 0.132 & 4.56 \\
Parathion-methyl & 21.208 & 0.071 & 3.00 & 0.098 & 4.46 \\
Pirimiphos-methyl & 22.146 & 0.063 & 3.29 & 0.089 & 3.90 \\
Fenitrothion & 23.121 & 0.052 & 2.79 & 0.077 & 3.65 \\
Chlorpyriphos & 23.267 & 0.064 & 2.85 & 0.080 & 3.90 \\
Malathion & 23.467 & 0.081 & 2.21 & 0.102 & 4.05 \\
Parathion & 23.796 & 0.046 & 3.03 & 0.066 & 4.90 \\
Bromofos-methyl & 24.956 & 0.052 & 2.35 & 0.068 & 4.40 \\
Chlorfenvinphos & 27.232 & 0.055 & 3.19 & 0.072 & 4.56 \\
Bromofos-ethyl & 27.346 & 0.051 & 1.71 & 0.089 & 3.98 \\
Fenamiphos & 31.029 & 0.051 & 2.18 & 0.097 & 4.87 \\
Ethion & 35.978 & 0.025 & 2.37 & 0.046 & 3.98 \\
Phosmet & 44.039 & 0.027 & 1.97 & 0.051 & 3.30 \\
Phosalone & 44.661 & 0.031 & 2.10 & 0.058 & 4.01 \\
Azinphos-methyl & 47.462 & 0.019 & 2.69 & 0.045 & 4.30 \\
\hline
\end{tabular}

From the obtained results, it can be noticed that the proposed method is accurate and precise enough for the determination of azinphos-methyl, bromofos-methyl, bromofos-ethyl, chlorfenvinphos, chlorpyrifos, diazinon, dimethoate, ethion, etrimfos, fenamiphos, fenitrothion, malathion, mevinphos, methacrifos, parathion, parathion-methyl, pirimiphos-methyl, phosalone, phorate and phosmet in corn. The obtained values for multiple correlation coefficients, ranged from 0.9935 to 0.9996 , indicated that the method has a good linearity for all the pesticides.

GC-NPD chromatograms of fortified blank corn samples with OPPs at $10 \mathrm{ng} / \mathrm{g}$ (a), as well as blank corn extract (b), are shown in Fig. 2.

\subsubsection{Repeatibility and Reproducibility}

The within day repeatability of our method was determined by performing the analysis of 10 blank samples fortified with OPPs at $20 \mathrm{ng} / \mathrm{g}$. After the extraction and purification the obtained extracts were analyzed by GC-NPD within the same day under the chromatographic conditions described in the section 2.1. The between day reproducibility of the method was determined by performing 
the analysis of the extracts obtained from 5 fortified blank sample (20 ng/g of OPPs). After the extraction and purification the extracts were analyzed within 5 different days, under the same chromatographic conditions (section 2.1). The calculated RSD values for the retention time $\left(t_{\mathrm{R}}\right)$, the peak areas, within day repeatability and between day reproducibility are shown in Table 4.

The calculated RSD values for within day repeatability for the $t_{\mathrm{R}}$ ranged from $0.019 \%$ to $0.13 \%$, whereas for peak areas RSD values ranged from $0.91 \%$ to $3.61 \%$, indicating good precision of the $t_{\mathrm{R}}$ within the same day. The calculated RSD values for between day reproducibility for the $t_{\mathrm{R}}$ ranged from $0.045 \%$ to $0.172 \%$, whereas for peak areas RSD values ranged from $1.23 \%$ to $4.90 \%$, indicating good precision of the $t_{\mathrm{R}}$ within different days.

\subsubsection{Stability}

Stock standard solutions and working standard solutions were found to be stable for at least 3 months, respectively, when stored at $4{ }^{0} \mathrm{C}$. Moreover, the stability of a fortified blank sample at a concentration of $20 \mathrm{ng} / \mathrm{g}$ kept in the auto injector for 24 hours was assayed, and differences of $<3.5 \%$ were obtained.

\subsubsection{Limit of Detection, Limit of Quantification, Measurement Unceratinty}

The limit of detection (LOD) and the limit of quantification (LOQ) were calculated according to the formulas $\mathrm{LOD}=3.3 \cdot \mathrm{SD} /$ slope and $\mathrm{LOQ}=10 \cdot \mathrm{SD} /$ slope [28]. The computed values for all the tested pesticides were found to be well below the MRLs (Table 5).

Table 5. Statistical data for $L O D, L O Q, U_{x}$ and MRLs for pesticide residues in corn

\begin{tabular}{lllll}
\hline Pesticide & $\begin{array}{l}\text { LOD } \\
(\mathbf{m g} / \mathbf{k g})\end{array}$ & $\begin{array}{l}\text { LOQ } \\
(\mathbf{m g} / \mathbf{k g})\end{array}$ & $\begin{array}{l}\mathbf{U}_{\mathbf{x}} \\
\mathbf{( \% )}\end{array}$ & $\begin{array}{l}\text { MRLs } \\
(\mathbf{m g} / \mathbf{k g})\end{array}$ \\
\hline Mevinphos & 0.0015 & 0.0045 & 12.5 & 0.01 \\
Methacrifos & 0.0010 & 0.0030 & 14.2 & 0.05 \\
Phorate & 0.0014 & 0.0042 & 11.3 & 0.05 \\
Diazinon & 0.0013 & 0.0039 & 12.9 & 0.01 \\
Dimethoate & 0.0011 & 0.0033 & 10.8 & 0.02 \\
Etrimfos & 0.0010 & 0.0030 & 9.6 & 5 \\
Parathion-methyl & 0.0012 & 0.0036 & 11.6 & 0.02 \\
Pirimiphos-methyl & 0.0009 & 0.0027 & 10.5 & 5 \\
Fenitrothion & 0.0012 & 0.0036 & 8.7 & 0.05 \\
Chlorpyrifos & 0.0015 & 0.0045 & 9.5 & 0.05 \\
Malathion & 0.0013 & 0.0039 & 11.2 & 8 \\
Parathion & 0.0011 & 0.0033 & 9.6 & 0.05 \\
Bromofos-methyl & 0.0012 & 0.0036 & 11.7 & - \\
Chlorfenvinphos & 0.0011 & 0.0033 & 13.4 & 0.02 \\
Bromofos-ethyl & 0.0012 & 0.0036 & 11.2 & 0.05 \\
Fenamiphos & 0.0011 & 0.0033 & 10.4 & 0.02 \\
Ethion & 0.0008 & 0.0024 & 10.6 & 0.01 \\
Phosmet & 0.0014 & 0.0042 & 12.3 & 0.05 \\
Phosalone & 0.0011 & 0.0033 & 10.9 & 0.01 \\
Azinphos-methyl & 0.0013 & 0.0039 & 13.7 & 0.05 \\
\hline & & & & \\
\hline
\end{tabular}

The values for measurement uncertainty $\left(\mathrm{U}_{\mathrm{x}}\right)$ were calculated according to a Eurachem/CITAC Guide [29]. The obtained values showed in Table 5, ranged from $8.7 \%$ to $14.2 \%$ and were in accordance with the recommended EU criteria [27].

\section{Conclusions}

A reliable, accurate and precise GC-NPD method, after extraction with ASE and the combination of liquid-liquid and SPE/PSA purification, was developed, optimized and validated for the simultaneous determination of azinphos-methyl, bromofos-methyl, bromofos-ethyl, chlorfenvinphos, chlorpyrifos, diazinon, dimethoate, ethion, etrimfos, fenamiphos, fenitrothion, malathion, mevinphos, methacrifos, parathion, parathion-methyl, pirimiphos-methyl, phosalone, phorate and phosmet in corn samples. With the proposed extraction procedure, the extraction and filtration can be performed in a single step requiring a low volume of organic solvent. The proposed purification procedure, reduce the amount of co extractible lipids and disables the appearance of the background peaks in the chromatogram, above signal to noise ratio of 3 , at the retention times of targeted pesticides. NPD was chosen for this analysis due to its selectivity for the compounds of interest. Validation parameters obtained for determination of OPPs in corn demonstrate that the developed analytical method meets the method performance acceptability criteria (mean recovery in the range $76 \%-112.0 \%$; precision with RSD $<8.2 \%$; LOQ < MRL; measurement uncertainty < $14.2 \%$ ). The results of validation and verification of the method in the international proficiency tests (FAPAS 0951) showed it's usefulness for routine analysis. Namely, the satisfactory $\mathrm{Z}$ scores were obtained for all present organophosphorus pesticides as: $Z=0.0$ for etrimfos, $Z=-0.2$ for fenitrothion, $Z=0.1$ for malathion and $Z=2.0$ for pirimiphos-methyl with not false positive $Z$ scores for any of the designated pesticides.

\section{References}

[1] R.J.Cremlyn, "Agrochemicals - preparation and mode of action". John Wiley \& Sons, Ltd. Baffins Lane, Chichester, West Sussex, England, pp.105 -145, 1991.

[2] D. J. Ecobichon, "Pesticide use in developing countries", Toxicology, vol. 160 (1-3), pp.27-33, 2001.

[3] T. Cserháti and M. Szőgyi, "Chromatographic determination of pesticides in food and food products", Eur.Chem. Bull., vol. 1(3-4), pp. 58-68, 2012.

[4] P. Cabras and A. Angioni, "Pesticides residues in grapes, wine and their processing products," Journal of Agricultural and Food Chemistry, vol. 48 (4), pp. 967-973, 2000.

[5] S. Navarro, J. Oliva, G. Navarro and A. Barba, "Dissipation of chlorpyrifos, fenarimol, mancozeb, metalaxyl, penconazole, and vinclozol in in grapes," American Journal of Enology and Viticulture," vol. 52 (1), pp.35-40, 2001. 
[6] T. Kostov and Z. Pacanoski, "Weeds with major economic impact on agriculture in the Republic of Macedonia ", Pak. J. Weed Sci. Res., vol.13 (3-4), pp.227-239, 2007.

[7] T. Đorđević, S. Šiler- Marinković, R. Đurović- Pejčev, S. Dimitrijević-Branković , J.Gajić and U. Miljendić, ", Efficiencies in different methods for determination of organophosphate pesticide residues in fermented wheat substrate", Pestic. Phytomed. vol. 28 (2), pp.133-140, 2013.

[8] U. Uygun, R. Uzkara, A. Uzbey and H. Koksel, "Residue levels of malathion and fenitrothion and their metabolites in postharvest treated barley during storage and malting", Food Chemistry, vol. 100 (3), pp. 1165-1169, 2007.

[9] J.Sonchieua, M.Benoit-Ngassoum, J. Bosco-Tchatchueng, A. Kumar-Srivastava and L.P.Srivastava, "Survey of pesticide residues in maize, cowpea and millet from northern Cameroon part I", Food Additives and Contaminants: Part B. vol.1 (3), pp.178-184, 2010.

[10] D .R.Sharma, R.B.Thapa, H.K.Manandhar, S.M. Shrestha and S.B.Pradhan, "Use of pesticides in Nepal and impacts on human's health and environment", The Journal of Agriculture and Environment vol. 13, pp. 67-74, 2012.

[11] Regulation (EC) No 396/2005 of the European Parliament and of the Council of 23 February 2005 on maximum residue levels of pesticides in or on food and feed of plant and animal origin and amending Council Directive 91/414/EECText.

[12] S. Zilić, M. Milasinović, D. Terzić, M. Barac and D. Ignjatović-Mičić, "Grain characteristics and composition of maize specialty hybrids", Spanish Journal of Agricultural Research, vol. 9 (1), pp. 230-241, 2011.

[13] B. Tang, J.E. Zhang, L.G. Zang, Y. Z. Zhang, X.Y. Li and L. Zhou, "Determination of nine organophosphorus pesticides in cereals and kidney beans by capillary gas chromatography with flame photometric detection", Journal of Chromatographic Science, 43 (7), pp. 337-341, 2005.

[14] M. B. Mariani, V. D'Aiuto and V. Giannetti, "Multiresidue method for the determination of organophosphorus pesticides in cereal matrixes",J. AOAC Int., vol.93 (3), pp. 999 - 1006, 2010 .

[15] D.H. Kim, G.S. Heo and D.W. Lee, "Determination of organophosphorus pesticides in wheat flour by supercritical fluid extraction and gas chromatography with nitrogen-phosphorus detection", Journal of Chromatography A, vol. 824 (1), pp. 63-70, 1998.

[16] P. Liu and Y. Ma, "Determination of 36 pesticide residues in corn using gas chromatography mass spectrometry", Journal of Hunan Agricultural University, vol. 7, pp. 1-13, 2005.

[17] Y. Hirara, M. Kimura, T. Inoue, Sh. Uchikawa, S. Otani, A. Haganuma, N. Matsumoto, A. Hirata, Sh. Maruyama, T. Ilizuka, M. Ukyo, M. Ota, H. Hirose, S. Suzuki and Y. Uchida, "Validation of multiresidue screening methods for the determination of 186 pesticides in 11 agricultural products using gas chromatography", Journal of Health Science, vol. 51(5), pp. 617-627, 2005.
[18] J. Zhao, "Gas Chromatography Simultaneous Determination of Fourteen Organic Phosphorus Residues in food", Analysis and Testing Technology and Instruments, vol. 18 (2), pp. 106 $-110,2012$.

[19] S. Hanwen, G. Xusheng , L. Yunkai and W. Anbang, "Application of accelerated solvent extraction in the analysis of organic contaminants, bioactive and nutritional compounds in food and feed", Journal of Chromatography A, vol. 1237, pp. 1-23, 2012.

[20] J. L Ezzell, B.E. Richter, W.D Felix., S. R. Black and J. E. Meikle, "A comparison of Accelerated Solvent Extraction with conventional solvent extraction for organophosphorus pesticides and herbicides", LC-GC, vol. 13, pp. $390-398$, 1995.

[21] B. Albero, C. Sánchez-Brunete and J. L. Tadeo, "Determination of organophosphorus pesticides in fruit juices by matrix solid - phase dispertion gas chromatography", Journal of Agricultural and Food Chemistry, vol. 51 (24), pp. 6915 - 6921, 2003.

[22] M. Anastassiades, S.J. Lehotay, D. Stajhbaher and F.J. Schenck, "Fast and easy multi-residue method employing acetonitrile extraction/partitioning and dispersive solidphase extraction for the determination of pesticide residues in produce”, J. AOAC Int., vol. 86 (2), pp. 412 - 431, 2003.

[23] S. Lehotay, A. de Kok, M. Hiemstra and P. van Bodegraven, "Validation of a Fast and Easy Method for the Determination of Residues from 229 Pesticides in Fruits and Vegetables Using Gas and Liquid Chromatography and Mass Spectrometric Detection”, J. AOAC Int., vol.88 (2), pp. 595 614, 2005.

[24] S. Lehotay, "Determination of Pesticide Residues in Foods by Acetonitrile Extraction and Partitioning with Magnesium Sulfate: Collaborative Study", J. AOAC Int., vol. 90 (2), pp. 485-520, 2007.

[25] M.H. EL- Saeid and M.T.Selim, "Multiresidue analysis of 86 pesticides using gas chromatography mass spectrometry: II no leafy vegetables", Journal of Chemistry, vol. 2013, pp. 1 10, 2013.

[26] F.J. Schenck, S.J. Lehotay and V. Vega, "Comparison of solid-phase extraction sorbents for cleanup in pesticide residue analysis of fresh fruits and vegetables", J. Sep. Sci. vol. 25 (14), pp. $883-890,2002$.

[27] Guidance document on analytical quality control and validation procedures for pesticide residues analysis in food and feed, European Commission, Directorate General Health and Consumer Protection, SANCO/12571 rev.0.0 , 2013.

[28] J.C. Miller and J. N. Miller, "Statistic for analytical chemistry", 3rd Ed., Ellis Horwood Ptr. Prentice Hall, pp. $104-141,1993$.

[29] Quantifying Uncertainty in Analytical Measurement, Eurachem/CITAC Guide CG 4, 3rd Ed., S. L. R. Ellison (LGC, UK), A. Williams (UK), pp. 4-31, 2012. 